\title{
THE AID OF SAINTS: RECLAIMING THE LIVES OF EARLY MEDIEVAL EXILES
}

\section{Steven A. Stofferahn}

In a field defined by a scarcity of sources, scholars of the early Middle Ages are obliged to accord careful consideration to all surviving materials, regardless of the challenges they pose. This is especially important in studying a political practice like exile, which not only removed troublesome characters from their immediate environs but also obscured whole phases of their lives from the historical record. As a result, reconstructing an exile's narrative can be an exercise in frustration. Annals, letters, and capitularies often convey part of the story but usually say little about what banishment was actually like, how it worked, or what the concerned parties thought about it. Given such obstacles, saints' lives-if treated with care and an awareness of their limitations - can serve as a promising repository of valuable information, not only for understanding this particular practice, but for shedding light on a range of important instruments of early medieval political culture.

As one of the most distinctive genres of medieval literature, the saint's life is familiar to all who study the Middle Ages. Hagiography enjoys a rich scholarly tradition in its own right, particularly given the centuries'-long work by the Société des Bollandistes of preserving saints' lives for posterity through the Acta Sanctorum. In providing a recent historiographical overview, Thomas Head has noted that the saint's life served many purposes and audiences, conveying not only the basic narratives of holy men and women but, more importantly, lifting them up to contemporaries as models of Christian behavior. This hortatory aspect invests the work with much of its value for historians, since, as he observes, it "can thus tell us at least as much about the author and about those who used the text - their ideals and practices, their concerns and aspirations - as it does about the saints who are their subjects. Hagiography provides some of the most valuable records for the reconstruction and study of the practice of premodern Christianity." 1

Still, historians have long debated the proper place of vitae among historical sources, and to what degree they can serve as worthy witnesses to the medieval past. Such sources present more than their share of interpretive problems; composed for audiences not including modern historians, vitae aimed more to inspire than to record. This problem-specifically the boundary between

\footnotetext{
${ }^{1}$ Thomas Head, ed., Medieval Hagiography: An Anthology (New York: Routledge, 2001), xiii. In addition to the Acta Sanctorum, he draws special attention to two seminal modern works on the subject: Jacques Dubois and Jean-Loup Lemaitre, Sources et méthods de l'hagiographie médiévale (Paris: Editions du Cerf, 1993) and Guy Philippart, ed., Hagiographies: Histoire international de la littérature hagiographique latine et vernaculaire en Occident des origins à 1500 (Turnhout: Brepols, 1994).
} 
hagiography and history — has been usefully explored in recent studies by Felice Lifshitz and Leah Shopkow. Limning the artificial nature of that boundary, Lifshitz has argued for a careful reconsideration of saints' lives from the perspective of how medieval audiences used them as core sources of information, rather than solely through the positivist framework applied by the discipline's modern architects, suspicious of texts highlighting the miraculous. ${ }^{2}$

Nonetheless, Shopkow_drawing from Hans Robert Jauss" "horizon of expectations" (referring to "the body of texts which influence both how an author shapes a text and how the reader interprets it")—-has maintained that there is value in preserving some distinction of genre, since medieval audiences themselves debated the veracity of miracles and recognized the difference between various kinds of narratives. ${ }^{3}$ On a less theoretical note, for at least a generation historians have attempted to distill bits of specific contextual information from saints' lives, inspired principally by Frantiŝek Graus' work in the 1960s using vitae as vital sources of social history. ${ }^{4}$ Still, one almost always encounters the tendency toward uniformity when it comes to medieval biography. As Thomas Head and Thomas F. X. Noble have observed, the specificity of a saint's experiences was often intentionally subsumed into a "generalized type of sanctity," since one of the outright purposes of the author was to show how the saint fit into the larger story of the faith. ${ }^{5}$ Those limitations notwithstanding, such accounts clearly comprise a vast storehouse of information about religion, economics, and society in early medieval Europe, not to mention the broad outlines of its distinctive political culture, since even hagiographical narratives had to resonate with their audiences' perceptions of reality.

The following study proposes to use at least some of the treasures from this trove to shed further light on the experience of early medieval exile. Merovingian, Anglo-Saxon, and Carolingian sources from the sixth through the tenth centuries

\footnotetext{
${ }^{2}$ Felice Lifshitz, "Beyond Positivism and Genre: 'Hagiographical' Texts as Historical Narrative," Viator: Medieval and Renaissance Studies 25 (1994): 95-113, with a particularly prescient observation on the Carolingian era: "The concept of a genre of 'hagiography' is a historiographical construction and, ipso facto, an ideological tool. It is a tool that had no function in the ninth, tenth, and eleventh centuries, and thus as a conceptual category did not exist. It should not be anachronistically applied in our analyses of late Carolingian and early Capetian Francia, because it can only obscure the realities of those centuries, not illuminate them" (113).

${ }^{3}$ Leah Shopkow, History and Community: Norman Historical Writing in the Eleventh and Twelfth Centuries (Washington, D.C.: Catholic University of America, 1997), 278-279.

${ }^{4}$ See Frantiŝek Graus, Volk, Herrscher und Heiliger im Reich der Merowinger: Studien zur Hagiographie der Merowingerzeit (Prague, 1965), whose importance is discussed in Head, Medieval Hagiography, xxix. Recent applications of this approach may be found in Michael McCormick, Origins of the European Economy: Communications and Commerce, A.D. 300-900 (Cambridge: Cambridge University Press, 2001), innovatively making use of "fictional" sources to discern the contours of early medieval communication and travel, though also noting that "[t]he only problem with these richly documented travelers is that they never existed" (267). More recently, Christina Roukis-Stern holds up the two saints' lives of her study as "prismatic works that teem with clues for understanding the changing culture and complexities of thirteenth-century spirituality." "A Tale of Two Dioceses: Prologues as Letters in the Vitae Authored by Jacques de Vitry and Thomas de Cantimpré," in Negotiating Community and Difference in Medieval Europe: Gender, Power, Patronage, and the Authority of Religion in Latin Christendom, ed. Katherine Allen Smith and Scott Wells (Leiden: Brill, 2009), 46.

${ }^{5}$ Thomas F. X. Noble and Thomas Head, eds., Soldiers of Christ: Saints and Saints' Lives from Late Antiquity and the Early Middle Ages (University Park: Pennsylvania State University, 1995), xviii.
} 
are replete with accounts of actions or offenses resulting in banishment, whether imposed by oneself or, more typically, by a displeased ruler. Exile as a Classical and late medieval political instrument has been well documented, but only a few scholars have investigated its use in the early Middle Ages. ${ }^{6}$ Studies by Kurt Metz and Adelheid Krah admirably assembled the details of scores of individual cases during this period but paid less attention to what exile was actually like, how such figures managed to regain their former positions, and why the practice was used in the first place. ${ }^{7}$ My own earlier studies have endeavored to show how exile resonated in Carolingian political culture vis-à-vis the cultural influences and political exigencies so determinative in the Frankish realms of the eighth to the tenth centuries. ${ }^{8}$ Here I wish to pursue this inquiry further, drawing more intently upon a range of contemporary saints' lives to illustrate some of the broad characteristics of the practice of exile. The quandary of proving the veracity of an individual's hallowed biography is thus at least partly avoided, and even formulaic narrative constructions may prove useful, since the purpose is to discern what contemporaries would have generally expected from the instituting of exile. With these potential advantages in mind, the essay will draw upon the various accounts of banishment in Ardo's Life of Benedict of Aniane, Stephen of Ripon's Life of St. Wilfrid, the Life of Ansbert, Bede's Life of Cuthbert, and Eigil's Life of Sturm to reconstruct part of the workings of early medieval exile, particularly with regard to the practice's ubiquity, strategies employed to survive the ordeal and ultimately gain redemption, as well as the uses of exile by hagiographical writers to achieve specific political goals in their own day.

A vital starting-point is to recognize exile's wide resonance within early medieval political culture - to the extent that, particularly during the reigns of Charlemagne and Louis the Pious, a member of the imperial nobility may well have expected to suffer banishment at some point. This proposition is well supported from the start by a survey of over 150 well-documented cases of exile during the Carolingian period but is also vividly attested in the Life of Benedict of Aniane, composed between 824 and 826 by one of this influential monastic reformer's former monks, Ardo.

\footnotetext{
${ }^{6}$ Representative studies of Classical and Renaissance exile include Ernst Ludwig Grasmück, Exilium: Untersuchung zur Verbannung in der Antike (Paderborn: Ferdinand Schöningh, 1978); Giuliano Crifò, Richerche sull' 'exilium' nel periodo repubblicano (Milan: Giuffrè, 1961); Randolph Starn, Contrary Commonwealth: The Theme of Exile in Medieval and Renaissance Italy (Berkeley: University of California, 1982); Desiderio Cavalca, Il bando nella prassi e nella dottrina giuridica medievale (Milan: A. Giuffrè, 1978), and Christine Shaw, The Politics of Exile in Renaissance Italy (Cambridge: Cambridge University Press, 2000).

${ }^{7}$ See Kurt Metz, "Die Exilierung als politische Maßnahme im Frankenreich sowie in Deutschland und Frankreich bis zum Ende des 10. Jahrhunderts, " Inaugural-Dissertation (University of Heidelberg, 1956) and Adelheid Krah, Absetzungsverfahren als Spiegelbild von Königsmacht: Untersuchungen zum Kräftverhältnis zwischen Königtum und Adel im Karolingerreich und seinen Nachfolgestaaten (Aalen: Scientia, 1987)

${ }^{8}$ Steven A. Stofferahn, "Banished Worlds: The Political Culture of Carolingian Exile, 750-900," $\mathrm{Ph} . D$. Dissertation (Purdue University, 2003), featuring an early exploration of the use of saints' lives in chapters 6 and 7. A more nuanced consideration of the punishment's resonance within early medieval politics may be found in my "Resonance and Discord: Rethinking Early Medieval Political Culture," Historical Reflections/Réflexions Historiques 36 (2010): 4-16; and, on biblical commentaries, "Nebuchadnezzar and Charlemagne: Exile in Ninth-Century Carolingian Exegesis," in Theodulf to Rashi: Studies on the Origins of European Biblical Scholarship, ed. Frans van Liere and Johannes Heil (Leiden: Brill, 2018).
} 
According to the vita, having been entrusted by Charlemagne's son, Louis, with reforming authority in his sub-kingdom, Benedict traveled throughout Aquitaine standardizing monastic practice to correspond more closely with the Rule of St. Benedict. But, Ardo noted, the devil very much hated to see this, and so inspired jealously among Benedict's clergy, royal advisers, counts, and other powerful figures, all of whom conspired to incite Charlemagne's wrath against the reformer. So it was that when Benedict came to court to seek an audience with the emperor, no one impeded his way, because

it was supposed that if he appeared in the emperor's presence he would not be allowed to return to his homeland, since imperial anger would be aroused against him. He went in, however, without trepidation, relying on God's pity and putting his hope in Him for love of whom he strove without reluctance. If he should be sentenced to undergo pain of exile, so be it. It would make his mind freer to serve God. If he should be removed from office, he explained that with deep yearning he had long desired that boon. But when he appeared in the emperor's presence heavenly piety inclined Charles's mind to such great peace that as soon as he saw Benedict he embraced him and with his own hand extended a cup to him. Thus he, whom envious men had said would be an exile from his own soil, returned to it with high honor. And so, with divine mercy overriding, those who tried to defame him actually praised him and showed him, whom they sought to render odious by lies, not only revered by the least, but also by the greatest. ${ }^{9}$

While valuable as a reflection of court intrigue, etiquette, and ritual, this anecdote also shows just what pride of place exile had in contemporaries' minds as a natural punishment for a ruler to impose. Certainly all those opposed to the reformer thought so, as did - according to Ardo-Benedict himself, who apparently half expected to be exiled. This leaves little question as to the currency of exile in Ardo's time or, as the vitae leads its readers to believe, at Charlemagne's court in particular.

Saints' lives can also provide valuable insights as to what one's life in exile may have been like, with an eye toward logistical concerns, means of support, and hopes for redemption during one's relegation. It is critical to remember that one of the purposes (and principal benefits) of exile was to avoid alienating the designated person or kin group permanently, in case a change of circumstances were to prompt a subsequent call to return home. Banishment could thus be

\footnotetext{
9 "Esto, exilii decerneretur subire laborem, mentem suam agebat famulari Deo securiorem. Quod si ab officio ne praeesset pelleretur, omni desiderio hactenus hoc se concupisse narrabat. At priusquam in conspectu imperatoris astitit, ad tantam superna pietas tranquillitatem ejus inflexit mentem, ut viso eo deoscularetur, eique poculum propria porrigeret manu: et quem aemuli a proprio solo autumabant fieri extorrem, ad eum rediit magno cum honore: sicque divina ordinante misericordia eum dum infamare conati sunt, praedicarunt; et quem mentiendo odiosum reddere studuerunt, hunc non solum minimis, verum etiam magnatibus venerandum ostenderunt." Ardo, Vita Benedicti, ed. Georg Waitz and Wilhelm Wattenbach, MGH SS 15 (Hanover: Hahn, 1887), 211; trans. Allen Cabaniss, The Emperor's Monk: A Contemporary Life of Benedict of Aniane by Ardo (Devon: Stockwell, 1979), 78. The giving of the cup as a symbol of concord here most likely had to do with the fact that Benedict had served as a cupbearer (pincerna) at the court of Pippin III. It was perhaps this earliest memory of Benedict that Charlemagne wished to recall, here with unmistakably ritualized connotations.
} 
expected to be difficult, but it was not intended to be deadly. Indeed, contemporary sources yield precious few cases of subjects killed with impunity. In this, Stephen of Ripon's Life of St. Wilfrid, the Life of Ansbert, and Eigil's Life of Sturm serve as informative case studies, since in addition to relating how such wanderers were expected to cope with their plight, they also illumine the potent means employed in reclaiming one's status - strategies illustrating a marked preference for ritualistic reconciliation.

Once stripped of rank, position, honores, and sometimes property, many exiles seem to have been released on their own recognizance, so long as they vacated the area stipulated or implied by the judgment - normally his or her native region or familial power base. ${ }^{10}$ That some may have become wanderers after a fashion is suggested by several oblique references in other hagiographical sources. The late seventh-century author of the Passion of Leudegar, for instance, made the intriguing observation that immediately following the death of king Childeric, "certain of those who had been sentenced to exile at his command returned without fear, like poisonous snakes after wintertime that come forth from their caves in the spring." 11 Yet a peripatetic existence can hardly have been very common. It seems much more likely that many sought out both old and new contacts during their time afield. This is clearly evident in the Life of Saint Wilfrid, composed around 720 by the Anglo-Saxon Stephen of Ripon (long known as Eddius Stephanus).

In the course of the narrative, the vita details the many challenges faced by the saintly bishop, including, of course, banishment. In a nod to the significant agency women often exercised behind the scenes, Stephen related how the Northumbrian king Ecgfrith was manipulated by his queen, Iurminburgh, into unjustly exiling Wilfrid from his see, setting in motion a long chain of events taking the deposed bishop as far away as Rome. ${ }^{12}$ Interestingly, Stephen paid special attention to the time Wilfrid spent in Francia between 679-680. En route to appeal his case to the pope, Wilfrid stopped at the court of the Frankish king Dagobert II, where he was treated as an honored guest, which, as Stephen informed his readers, was "a return for former favors from Wilfrid." As it turns out, Dagobert had himself been banished to Ireland as a child, but when his rivals had fallen from power, Stephen says, his family sent a message to Wilfrid asking him to locate the young man and send him home so that he might assume his rightful place on the throne. Wilfrid happily complied, even going so far as to present him with arms and to outfit the troops that accompanied him home. As Stephen made sure to note, "The king did not forget such kindness."13 Now that Wilfrid was the one in need, Dagobert presented him with sumptuous gifts, even

\footnotetext{
${ }^{10}$ Stofferahn, "Banished Worlds," 171-207.

11 "Igitur cum Childerici mors subito nuntiata fuisset, tunc hii qui ob eius iussionem exilii fuerant condemnati, tamquam verno tempore post hiemem solent de cavernis serpentia venenata procedere, quidam sine metu fuerunt reverse." Passio Leudegarii episcopi et martyris Augustodunensis, ed. Bruno Krusch, MGH SSrM 5 (Hanover: Hahn, 1910), 296; trans. Alexander Callander Murray, From Roman to Merovingian Gaul (Peterborough: Broadview, 2000), 516.

${ }^{12}$ Stephen of Ripon (Eddius Stephanus), Vita Sancti Wilfridi, ed. Wilhelm Levison, MGH SSrM 6 (Hanover: Hahn, 1913), 218-219.

${ }^{13}$ Stephen of Ripon, Vita Sancti Wilfridi, 221-222.
} 
offering to install him as the bishop of Strasbourg. Wilfrid thanked him for his kindness but declined the offer, preferring to return to his own bishopric.

After procuring a favorable ruling from pope and council alike in his suit for reinstatement to the Northumbrian see, Wilfrid and his companions set off for home. But when they reached Francia, they discovered that Dagobert had been murdered. Even worse, one of the conspirators, a bishop, now headed the army blocking Wilfrid's way, bent on revenge against all supporters of the former king. Intending, Stephen recounts, to rob the companions, sell them into slavery, and deliver Wilfrid himself to the wicked duke Ebroin (who had engineered Dagobert's assassination in the first place), the conspirators paused to relish the moment:

"What made you so bold," they demanded, "as to pass through the land of the Franks, seeing that you deserve to be put to death for making Dagobert king? You it was who brought him back from exile and what did he do but lay waste our cities, spurn the advice of our elders, act like Solomon's son Rehoboam in imposing a humiliating tribute on his people, and despise the Church of God and her rulers? These are the crimes for which he was slain; this is the reason his body now lies in the grave."

To which Wilfrid calmly responded:

"In the name of Jesus Christ what I say is true; by the holy apostle Peter I swear I do not lie. It was in accordance with God's command to the people of Israel when they dwelt as strangers in a foreign land that I helped and cherished King Dagobert, then an exile and a wanderer. I raised him up not to your harm but for your good, sending him to build up your cities, to put spirit into your citizens, to counsel your senate, and, as he promised in the Lord's name, to defend the Church. Most righteous bishop, if an exile of my own country, and one of royal blood, had come to your lordship, where else would your duty have lain?"

Suddenly—even miraculously—contrite, the Frank replied:

"The Lord preserve your goings out and your comings in. Woe to me, sinner that I am! Pardon me, for, like the patriarch Judah, I see you are more righteous than I. The Lord be with you, and may the apostle Peter be your aid." 14

\footnotetext{
14 "Interrogavitque eum episcopus, dicens, qua fiducia tam temerarie per Francorum regionem pergisset: 'Qui dignus es morte, quia nobis regem subsidio tuo factus exilio emisisti, dissipatorem urbium, consilia seniorum despiciens, populos ut Roboam filius Salomonis tributo humilians, ecclesias Dei cum praesulibus contempnens; quorum malorum poenas luens occisus, cadaver eius humatum iacet.' Sanctus vero pontifex noster humiliter respondit episcopo: 'Veritatem dico in Christo Iesu et per sanctum Petrum apostolum non mentior, quia talem virum exulantem et in peregrinatione degentem secundum praeceptum Dei populo Israhelitico, qui accola fuit in terra aliena, auxiliatus enutrivi et exaltavi in bonum et non in malum vestrum, ut aedificator urbium, consolatory civium, consiliator senum, defensor ecclesiarum Dei in nominee Domini secundum promissum eius esset. $\mathrm{O}$ rectissime episcope, quid aliud habuisti facere, si exul de genere nostro et semine regio ad sanctitatem
} 
This lively narrative provides some telling clues as to what contemporaries seem to have expected in such a situation, particularly when it came to the means of support available to an exile. In Wilfrid's case, the special relationship he had cultivated with Dagobert certainly indicates an expectation of being able to fall back on acquaintances, especially those who may have had some experience with exile themselves. Interesting, too, is the implication through Wilfrid's reference to Israel's sojourn in Babylon that even in cases where no close relationships already existed, one might legitimately expect to find shelter and sustenance provided all the more hospitably because of being in a state of exile.

Saints' lives likewise contain interesting clues as to strategies employed in securing one's return to home and position. Despite exile's ubiquity, few would have expected it to be permanent, since the volatility of early medieval politics implied that a return from banishment was not only possible, but perhaps even likely. ${ }^{15}$ The most obvious route was simply to come back and not wait for anyone's permission, although such raw initiative was risky and rarely met with success. One could also simply wait for the situation to change enough to enable a quiet return home. In a telling passage of Bede's Life of Cuthbert, for instance, Aelfflaed, sister to the present king Ecgfrith, begs the holy Cuthbert to tell her who would assume the Northumbrian crown when Ecgfrith died, since he had no apparent heir. After long resisting, Cuthbert finally relents:

"Do not say there is no heir. One will come whom you will embrace with as much sisterly affection as though he were Ecgfrith's own self." "Then tell me where he is!" she cried. "Look at the sea," he replied. "It abounds in islands. God could easily provide a ruler for the English from one of them." She realized he was hinting at Aldfrith, the supposed son of Ecgfrith's father, who was away in Ireland being educated. ... His prophecy was completely fulfilled; next year Ecgfrith was slain by the Picts and the throne went to his bastard brother Aldfrith recently returned from his studies in Ireland, where he had willingly exiled himself for the love of learning. ${ }^{16}$

In addition to providing a representative sample of exile's close association with the sea in other insular sources, Bede's narrative also points to the widespread

tuam perveniret, quam quod ego in Domino feci?' Respondit episcopus: 'Dominus custodiat introitum tuum' et reliqua, et: 'Vae mihi peccatori, da indulgentiam, quia secundum Iudam patriarcham video te multo iustiorem me esse. Sit Dominus vobiscum, et sanctus Petrus apostolus in auxilio vestro." Stephen of Ripon, Vita Sancti Wilfridi, 227-228; trans. J. F. Webb, The Age of Bede (London: Penguin, 1965), 142-43.

${ }^{15}$ Stofferahn, "Banished Worlds," 208-244.

16: "Qui parum silens: 'Ne, inquit, dicas quia caret; habebit enim successorem, quem germana ut ipsum Ecgfridum dilectione complectaris.' At illa: 'Obsecro, inquit, dicas quibus in locis sit ille?' Qui ait: 'Cernis hoc mare magnum et spatiosum, quot abundet insulis? Facile est Deo de aliqua harum sibi providere quem regno praeficiat Anglorum.' Intellexit ergo quia de Aldfrido diceret, qui ferebatur filius fuisse patris illius, et tunc in insulis Scotorum ob studium litterarum exsulabat. . . Atque ut verbis ejus propheticis per omnia satisfieret, Ecgfridus post annum Pictorum gladio trucidatur, et Aldfridus in regnum frater ejus nothus substituitur, qui non paucis antea temporibus in regionibus Scotorum lectioni operam dabat, ipse ob amorem sapientiae spontaneum passus exsilium." Bede, Vita sancti Cuthberti, ed. J. P. Migne, Patrologia Latina 94 (Paris, 1850), 764; trans. Webb, The Age of Bede, 102-03. 
contemporary assumption that exiles could in fact expect to return, even in seemingly hopeless cases.

It was far more common, however, to try to secure a ruler's forgiveness. The question was how best to procure such a pardon, whether through one's own efforts, or by appealing to a third party to intervene on one's behalf. Begging the pope to intervene was one option but was hardly the only recourse open to those exiles who looked to the Church for help. Indeed, sacred intervention could also come in the form of concerted group pressure, particularly through prayer. This, at least, was the view expressed in the Life of Sturm, composed in 794 by the monk Eigil to recount the experiences of abbot Sturm of Fulda. The author paid special attention to the abbot's banishment between 763-765, attributing this undeserved punishment to archbishop Lull of Mainz, who wished to curtail Fulda's independence. The vita relates that the devil, seeing a prime opportunity to practice his craft, stirred up discontent in the abbey and prompted three brothers (supported by Lull) to come forward in the presence of king Pippin to levy false charges against their abbot. Pressing his advantage, Lull then persuaded the king to banish Sturm far from his native abbey. The latter, accompanied by a few monks as companions, was duly sent away to Jumièges, to be guarded by Droctegang, one of the king's most trusted supporters. Meanwhile, Lull had installed his own man, Marcus, as the new abbot of Fulda, but as he was so unlike Sturm, "he remained a stranger to them, and their manners did not agree."17 In fact, said Eigil, the situation deteriorated to such a point that not only did all the churches and abbeys in the east raise a hue and cry over Sturm's unfair treatment, the monks of Fulda even took matters into their own hands, expelling Marcus and threatening to go to Pippin's court to demand Sturm's return. Frightened but not yet cowed, Lull permitted them to choose a new abbot from among themselves. Accordingly they elected Prezzold, who had been raised in the monastery by Sturm, but continued to strategize - with the help of the abbey's founder and patron saint, Boniface- - how they would secure Sturm's return. They at last settled on prayer as the most natural solution:

They implored God in unceasing prayer to use His invincible power to bring their master back to them. And when they had done this for a long time and all the churches, monasteries, and convents in the eastern parts had joined in continual prayer with them, God, the comforter of the lowly, heard the prayers of His supplicants. And He put it into the heart of king Pippin to think about blessed Sturm. ${ }^{18}$

\footnotetext{
17 "sed quoniam fratres animos suos ab illo propter prioris amorem avertebant, erat eis quasi extraneus, et non conveniebant mores ipsorum." Eigil, Vita sancti Sturmi, ed. Georg H. Pertz, MGH SS 2 (Hanover: Hahn, 1829), 374; trans. Noble and Head, Soldiers of Christ, 181.

18 "Porro cum Prezzoldus de Patre et magistro suo Sturme profunde cogitaret, et sancti fratres cum eo de absentia ejus multo moerore afficerentur, Dei omnipotentis praesidium continuis precibus postulabant, ut ipse, cui nihil impossibile est, per suam invictam potentiam praestaret, quatenus ad eos illorum magister venire permitteretur. Quod cum per se diutius fecissent, et omnes orientales ecclesias, per omniaque monasteria servorum et ancillarum Dei in circuitu orationes incessabiles essent ad Deum pro eo, consolator humilium Deus preces exaudivit supplicantium. Et quia hoc constituit ut postularetur, precibus fidelium annuens, suscitavit cor Pippini regis, ut de beato Sturme cogitare coepisset." Eigil, Vita sancti Sturmi , 374; trans. Noble and Head, Soldiers of Christ, 181-82.
} 
The bedraggled exile was duly brought to the palace, presumably to receive harsher punishment.

Eigil then concludes his tale by providing a fascinating glimpse of early medieval symbolic communication by way of a remarkable exchange between king and abbot:

When Sturm had come in haste to the palace he waited in the king's chapel for several days, praying to God and waiting on the king's pleasure. It happened one day that as the king was going out to hunt and, as was his custom, came at dawn to pray, the rest of the king's servants were taking their rest after morning vigils. Sturm was praying alone, and, seeing the king about to enter, opened the doors of the church for him and led him to the altar with a lighted candle. When the king had humbly prayed to God at the sacred altars, he rose and, gazing on Sturm, he said with a smile: "God has brought us together at this moment. What the accusation was that your monks made against you in my presence I cannot remember, and why I was enraged against you I cannot recall." Then without hesitation Sturm answered: "Although I am not free from sin, never, O King, have I committed any crime against you." Then the king said: "Whether or not you have ever conceived an evil design against me or have done me any wrong, may God forgive you as I do from my heart. For the future, enjoy my favor and friendship all the days of my life." And taking a thread from his cloak, he let it fall to the ground and said: "Lo, as witness of perfect forgiveness, I cast this thread from my cloak on the ground that all may see that my former enmity against you is annulled." And so, reconciled and firmly united in friendship, the king set out on the expedition he had prepared. ${ }^{19}$

So pardoned by the king, Sturm returned in glory to his home abbey, which in turn received royal confirmation of its immunity from the archbishop's authority. Eigil further enhanced the triumph by noting that Fulda continued to build upon

\footnotetext{
19 “Qui cum adductus ad palatium concite fuisset, et ibi in capella regis per plures esset dies Deum orans, exspectans quid ei rex imperasset, contigit quadam die, ut in venationem rex pergeret, ac, ut solitus erat, ad orationem primo diluculo veniret, et caeteri servi Dei post vigilias matutinas quiescerent. Solus Sturmi vigilabat, et ingressum regis observans, januas ei ecclesiae aperuit, et cum claro lumine ad orationem ante eum ibat. Rex vero cum ad sacras aras Deum regem humiliter exorasset, erexit se, et alacri obtutu Sturmen intuitus: Dominus, dixit, congregavit nos modo; et, quid hoc fuit, quod monachi tui apud nos te accusaverunt, nescimus; et unde irati fuimus contra te, ignoramus. Sturmi vero constanter ait: Licet a peccatis immunis non sim, contra te tamen, o rex, delictum non feci. At ille: Sive, inquit, unquam aliquando contra me nequiter cogitaveris, aut inique aliquid gesseris, Deus tibi totum dimittat, et ego ex meo corde ignosco; et deinceps esto, ait, in gratia et in amicitia mea omni tempore. Tollensque manu sua de pallio] suo filum, projecit in terram, et dixit: Ecce in testimonium perfectae remissionis filum de pallio meo projicio in terram, ut cunctis pateat quod pristina deinceps annulletur inimicitia. Ita pacati firmiterque in amicitia fundati, rex iter quod coeperat, arripuit." Eigil, Vita sancti Sturmi, 374; trans. Noble and Head, Soldiers of Christ, 182. I am not aware of any similar ritual recorded for this era, but an inverted variation of the ritual of the thread appears in Raoul de Cambrai, the early thirteenth-century chanson de geste in which Bernier breaks fealty with his lord Raoul by plucking three hairs from his ermine cloak and throwing them to the ground between them. See Raoul de Cambrai, trans. Jessie Crosland (Cambridge, Ontario: Parentheses, 1999), 42.
} 
this foundation even after the death of Pippin III in 768, as Sturm likewise enjoyed the friendship of king Charles.

There were thus always higher authorities - including the divine - to which one could appeal for intercession. As Mayke de Jong has compellingly shown, such powers of prayer were not merely the fantasy of hagiographers; calls for divine intercession were accorded great respect in this era, and in fact figured significantly into the wider debate that emerged among important Carolingian circles in the ninth century about the acceptable bounds of exile itself. ${ }^{20}$ The Life of Sturm likewise bears witness to the important role ritualized behavior played in early medieval political culture, especially when it came to effecting redemption and reconciliation. Political performances ultimately had much more to do with fulfilling prearranged, negotiated rites and in allowing both sides of a conflict to save face, rather than in expressing the parties' actual views of the situation in question. In this case, Eigil clearly had an agenda, and worked hard to balance the need to maintain respect of the Carolingian ruler portrayed in his narrative with the desire to exonerate his subject from any possible wrongdoing. The fact that Sturm and Pippin come closer to resembling equals than subject and ruler by the end of their interchange was the result - unorthodox, perhaps, from the perspective of the court in 794, but very much in line with the expectations of Eigil's primary monastic audience.

Above all, the return from banishment again illustrates exile's most telling hallmark: its flexibility. That exile resonated on several levels of early medieval political culture was, after all, largely a function of its implicit promises. There was, for instance, an understanding between royalty and nobility of shared authority in the assigning and negating of such an awe-inspiring punishment. The promise of flexibility was likewise fulfilled not only by one's return from exile, but also the restoration of one's office, honores, property, and stature. If, as the vitae examined here appear to corroborate, nobles may have expected to be exiled at some point or another in their careers, then they also expected to return and to regain access to whatever means of support they had earlier enjoyed. Even Charlemagne, the most formidable of all Frankish rulers, found himself in need of aristocratic support in his endeavors, and the power of the latter would only increase under his successors. The path to redemption illustrated here therefore makes sense vis-à-vis the understanding of Carolingian sovereignty as open to the competing designs of a great many political elites rather than as an experiment in proto-absolutism.

Finally, in addition to providing historians with practical insights into an exile's survival, negotiation, and redemption, saints' lives also gave their authors the opportunity to advocate specific political agendas on occasion. For this one may look to the Life of Ansbert, relating the tale of Ansbert, abbot of St. Wandrille and bishop of Rouen, deposed and exiled around 690 for his alleged opposition to

\footnotetext{
${ }^{20}$ Mayke de Jong, "Carolingian Monasticism: The Power of Prayer," in The New Cambridge Medieval History, ed. Rosamond McKitterick, Vol. 2 (Cambridge: Cambridge University Press, 1995), 622-53. See also Steven A. Stofferahn, “A New Majesty: Paschasius Radbertus, Exile, and the Masters' Honor," in Medieval Monks and Their World: Studies in Honor of Richard Sullivan, eds. Amy Livingstone, Michael Frassetto, and David Blanks (Leiden: Brill, 2006), 49-69, for an account of Paschasius Radbertus' determined hagiographical attempt to rehabilitate the memory of his monastic mentors by proposing a novel understanding within Carolingian politics of who did (and who did not) have the authority to impose sentences of exile.
} 
Pippin II. The anonymous author, who spends a good amount of time on Ansbert's banishment, maintains that, though wrongly accused, the abbot nobly endured his punishment, becoming a model of piety in his new home at Hautmont—so much so, in fact, that everyone wished to be near him. Seeing this, his enemies complained to the king that the confinement was far too lenient, but Ansbert's guard rebuffed these arguments, even managing to convince Pippin to allow the captive to return home. Confronted with this development, Ansbert surprised everyone by declining the offer, preferring instead to follow the example of the martyrs and remain in exile, asking only that he be allowed burial in his home monastery of St. Wandrille. ${ }^{21}$

On the face of it, little seems out of the ordinary in the Vita Ansberti, well illustrating as it does the practice of relegating a potential threat to an area more solidly under one's control (eastward to Hautmont in Pippin's case). Much more, however, went into this vita than the nuts and bolts of relegation, particularly if one considers the circumstances of its composition through the lens of an institutional memory of exile. Ansbert's vita was composed long after the subject's death - sometime between the end of the eighth century and 811which begs the question of why the time seemed so ripe to commit Ansbert's story to parchment at this particular juncture. Any answer must remain largely conjectural, but certain events of the time may have strongly influenced the shape that this particular work took, perhaps in the hopes of influencing, in turn, a particular audience. In reading the vita itself, one certainly finds familiar patterns, but these appear to be more than established hagiographical topoi, since extensive attention is paid to the subject's undeserved expulsion from his home. Indeed, Ansbert's exile is the defining theme of the work. As noted earlier, however, the story incorporates an equal emphasis on its hero's acceptance of his fate- to such a degree that even when given the chance to escape, Ansbert decides it is actually preferable to remain in exile than to return to the troubles of his former life.

Seen in this light, Ansbert's vita resembles a consolation text of sorts. If so, then one prominent possible intended subject suggests itself above all others: Tassilo, Duke of Bavaria, who, after being deposed in 788 by his cousin Charlemagne, had been relegated to Jumièges, one of Rouen's daughter houses. ${ }^{22}$ Contemporary annals and narrative sources have relatively little to say about Tassilo's tenure in exile, but synodal records point out that he was escorted to the imperial assembly at Frankfurt in 794 to abdicate his ducal authority once and for all. Charlemagne's plans for expansion called for an integration of Bavaria into the greater Frankish realm; thus, the office of duke itself was to be abolished, and all authority vested directly in the person of the king. To add legitimacy to the process, however, the king required the willing assent of his cousin at the assembly. No doubt a range of options was considered as to the best way to ensure the former duke's cooperation. Tassilo and his entire immediate family had already been tonsured or veiled and committed to monastic exile, so there was

${ }^{21}$ Vita Ansberti episcopi Rotomagensis, ed. Wilhelm Levison, MGH SSrM 5 (Hanover: Hahn, 1910), 635 .

${ }^{22}$ The details of the various confinements to which Tassilo and his family were subjected are conveniently summarized by Sigurd Abel and Bernhard Simson, Jahrbücher des fränkischen Reiches unter Karl dem Großen, Vol. 1 (Berlin: Duncker and Humblot, 1888), 627-28. For a recent treatment of Tassilo's fate at the hands of the Carolingians, see Carl I. Hammer, From Ducatus to Regnum: Ruling Bavaria under the Merovingians and Early Carolingians (Turnhout: Brepols, 2007), 137-200. 
little leverage to be had in that arena. It is certainly possible that the king's advisors may have turned to the realm of devotional literature to help cajole Tassilo to comply at Frankfurt. The imagery incorporated into the Life of Ansbert definitely would have resonated with Charlemagne's agenda. Ansbert, after all, had reconciled himself with his own perpetual state of exile, even characterizing it as an honor. Tassilo must have known that he would never be allowed to return to secular affairs, although one doubts that he had would have come to peace with that reality, perhaps holding onto some sliver of hope of receiving pardon and restitution someday as so many other exiles did. In this case, however, that day was not going to come, and the king's advisors may have essentially commissioned this work, in part, to help convey that reality to the monastery's most famous resident. No one can say for sure, of course, but circumstances would seem to point toward this tantalizing possibility, subtly raised by the author of a vita intimately aware, no doubt, of the rocky events marking Tassilo's own life.

Even under the best of circumstances, an exile's life can be difficult to piece together, both at the time and in posterity. With patchy source material, it is rarely possible to construct a complete biography, thereby prompting the attempt to fill in the gaps with at least archetypal elements. As the essay's exemplars show, saints' lives can serve as a key foundation for that work, as they often reveal not just specific details, but also probable courses of action applicable to most exiles and glimpses into the subtler workings of early medieval political culture. Their stories reiterate the ubiquity of banishment, and therefore its core resonance within the noble-royal relationship. Additionally, exiles' activities, travels, and interactions highlight their potential range of action, as well as the importance of ritual communication in the early Middle Ages. Finally, vitae may even occasionally provide crucial details about the careers of important figures, particularly for parts of their lives that were not meant to be known. Despite their difficulties, the careful use of these important contextual sources can thus be well worth the effort, as they provide vibrant opportunities for those seeking to overcome a dearth of sources for an era so rich in traditions.

Indiana State University 


\section{Bibliography}

Abel, Sigurd and Bernhard Simson. Jahrbücher des fränkischen Reiches unter Karl dem Großen. Vol. 1. Berlin: Duncker and Humblot, 1888.

Ardo. Vita Benedicti. Ed. Georg Waitz and Wilhelm Wattenbach. Monumenta Germaniae Historica: Scriptores 15: 198-220. Hanover: Hahn, 1887.

Bede. Vita sancti Cuthberti. Ed. J. P. Migne. Patrologia Latina 94: 733-790. Paris, 1850.

Cabaniss, Allen. The Emperor's Monk: A Contemporary Life of Benedict of Aniane by Ardo. Devon: Stockwell, 1979.

Dubois, Jacques and Jean-Loup Lemaitre. Sources et méthods de l'hagiographie médiévale. Paris: Editions du Cerf, 1993.

Eigil. Vita sancti Sturmi. Monumenta Germaniae Historica: Scriptores 2: 365377. Ed. Georg H. Pertz. Hanover: Hahn, 1829.

Graus, Frantisisek. Volk, Herrscher und Heiliger im Reich der Merowinger: Studien zur Hagiographie der Merowingerzeit. Prague, 1965.

Hammer, Carl I. From Ducatus to Regnum: Ruling Bavaria under the Merovingians and Early Carolingians. Turnhout: Brepols, 2007. https://doi.org/10.1484/M.HAMA-EB.5.106049

Head, Thomas, ed., Medieval Hagiography: An Anthology. New York: Routledge, 2001.

Jong, Mayke de. "Carolingian Monasticism: The Power of Prayer." In The New Cambridge Medieval History, ed. Rosamond McKitterick, vol. 2, 622-653. Cambridge: Cambridge University Press, 1995.

Lifshitz, Felice. "Beyond Positivism and Genre: 'Hagiographical' Texts as Historical Narrative." Viator: Medieval and Renaissance Studies 25 (1994): 95-113. https://doi.org/10.1484/J.VIATOR.2.301209

McCormick, Michael. Origins of the European Economy: Communications and Commerce, A.D. 300-900. Cambridge: Cambridge University Press, 2001. https://doi.org/10.1017/CBO9781107050693

Murray, Alexander Callander, ed. From Roman to Merovingian Gaul. Peterborough: Broadview, 2000.

Noble, Thomas F. X. and Thomas Head. Soldiers of Christ: Saints and Saints' Lives from Late Antiquity and the Early Middle Ages. University Park: Pennsylvania State University, 1995.

Passio Leudegarii episcopi et martyris Augustodunensis. Ed. Bruno Krusch. Monumenta Germaniae Historica: Scriptores rerum Merovingicarum 5: 249362. Hanover: Hahn, 1910. 
Philippart, Guy, ed. Hagiographies: Histoire international de la littérature hagiographique latine et vernaculaire en Occident des origins à 1500. Turnhout: Brepols, 1994.

Raoul de Cambrai. Trans. Jessie Crosland. Cambridge, Ontario: Parentheses, 1999.

Roukis-Stern, Christina. "A Tale of Two Dioceses: Prologues as Letters in the Vitae Authored by Jacques de Vitry and Thomas de Cantimpré." In Negotiating Community and Difference in Medieval Europe: Gender, Power, Patronage, and the Authority of Religion in Latin Christendom, ed. Katherine Allen Smith and Scott Wells, 34-47. Leiden: Brill, 2009.

Shopkow, Leah. History and Community: Norman Historical Writing in the Eleventh and Twelfth Centuries. Washington, D.C.: Catholic University of America, 1997.

Stephen of Ripon (Eddius Stephanus). Vita Sancti Wilfridi. Ed. Wilhelm Levison. Monumenta Germaniae Historica: Scriptores rerum Merovingicarum 6: 193263. Hanover: Hahn, 1913.

Stofferahn, Steven A. "Banished Worlds: The Political Culture of Carolingian Exile, 750-900.” Ph.D. Dissertation, Purdue University, 2003.

_. "A New Majesty: Paschasius Radbertus, Exile, and the Masters' Honor." In Medieval Monks and Their World: Studies in Honor of Richard Sullivan, ed. Amy Livingstone, Michael Frassetto, and David Blanks, 49-69. Leiden: Brill, 2006. https://doi.org/10.1163/9789047411369_005

"Nebuchadnezzar and Charlemagne: Exile in Ninth-Century Carolingian Exegesis." In Theodulf to Rashi: Studies on the Origins of European Biblical Scholarship, ed. Frans van Liere and Johannes Heil, 381-398. Leiden: Brill, 2018.

_. "Resonance and Discord: Rethinking Early Medieval Political Culture." Historical Reflections/Réflexions Historiques 36 (2010): 4-16. https://doi.org/10.3167/hrrh.2010.360102

Vita Ansberti episcopi Rotomagensis. Ed. Wilhelm Levison. Monumenta Germaniae Historica: Scriptores rerum Merovingicarum 5: 613-643. Hanover: Hahn, 1910.

Webb, J. F. The Age of Bede. London: Penguin, 1965. 